\title{
The Conflict between the Principles of the National Identity of Member States AND VAlues of European UNion Such as Rule of LAW, Respect FOR Human Rights AND Liberal Democracy - Case Study of Hungary
}

\author{
Kumush Suyunova \\ Palacký University Olomouc, Czech Republic \\ kumush.suyunova@mail.ru
}

SUYUNOVA. Kumush. The Conflict between the Principles of the National Identity of Member States and Values of European Union Such as Rule of Law, Respect for Human Rights and Liberal Democracy - Case Study of Hungary. International and Comparative Law Review, 2020, vol. 20, no. 2, pp. 159-173. DOI: $10.2478 /$ iclr-2020-0022

\begin{abstract}
Summary: Human rights are indivisible. The EU holds resolute tone against the challenges of universal human rights. As an adequate method of governance the EU acknowledges the rule of law that encompasses transparent and reliable legal system, an independent judiciary, prevention of arbitrary executive power; legal egalitarianism and respect for rights and freedoms of individuals. The concept of democracy determines the values behind the governance of a country. Thus, the EU's vision of democracy comprises several principles: political equality, representative and participative democracy, which include fair elections, separation of power, effective checks and balances. However, despite the EU's efforts to promote human rights, rule of law and democracy, some member States are still lagging behind the overall positive achievement. Hungary, who pick up illiberal democracy over established European values, has become the focus of attention.
\end{abstract}

Keywords: fundamental values, human rights, rule of law, liberal democracy, national interests, infringement procedure.

\section{Introduction}

The European Union (EU) is standing firm in the face of threats of fundamental human rights. Respect for human rights connects the cycle of sustainable development and democracy and the primacy of law is the common ground for all. The absence of justice directly affects the process of development, since, on the one hand, it opens the way to abuse of power, and, on the other, it negatively affects citizens' rights and legitimate interests. It is clear that sustainable democratic development is impossible without complying with the rule of law ${ }^{1}$.

1 BOUTROS-GHALI, Boutros. Interdependence of democracy and development. France, SHS-2003/WS/24, UNESCO, 2003, p.11. 
Despite the endeavors of the EU to enhance the protection of human rights, rule of law and promotion of democracy, some Member States (MS) still lag behind the overall positive achievement. Nowadays, Hungary, which is picking up illiberal democracy over proven European principles, has become the focal point. The case study of Hungary helps to understand the practical implementation of EU concepts in the field of human rights, democracy and the rule of law, which raises concerns about the relationship between the concept of national interests and the sustainability of EU's fundamental values.

It is well known, as O.Hamulák and others say, that the EU offers a general structure for the protection of human rights, which the CJEU uses for interpretation. In reference to the EU Charter of Fundamental Rights the scholars claim, that EU law does not establish fundamental rights which, in all cases, are of general application to and within a Member State ${ }^{2}$. They, therefore, suggest that the reason why the EU has human rights issues in practice is that the EU Charter of Fundamental Rights has no diagonal application in theory: it is addressed, in principle, to the institutions of the EU and it applies to the Member States only when they implement the EU law. ${ }^{3}$

With respect to fundamental freedoms, the European Court of Justice (ECJ) has acknowledged the national constitutional law of the Member State (MS) to comprise essential element of national identity. However, it must be highlighted that the notion of national identity of the MS can raise serious questions with regard to the protection of human rights in those states, issues of dignity, equality the rule of law and democracy. Thus, in case of Hungary, this paper focuses on how the discrepancy may arise between the notion of sovereignty of the MS and EU principles and values, and how the very issue of preserving MS's identity under Article 4(2) can have negative impact on the efficiency of the mechanism of protection of human rights in the EU level ${ }^{4}$.

Based on above-said, our research question will be: how EU can eliminate the democratic deficit in MS and protect the principles set out in Article 2 of the Treaty on European Union (TEU)?

The aim of this work is to understand the current challenges and to give an idea of how soft power principles and other mechanisms have been used to elim-

2 HAMULÁK, Ondrej, SULYOK, Márton, KISS, Lilla Nóra. Measuring the 'EU'clidean Distance between EU Law and the Hungarian Constitutional Court - Focusing on the Position of the EU Charter of Fundamental Rights. Czech Yearbook of Public and Private International Law, 2019, vol. 10, no. 1, p 138.

3 HAMULÁK, Ondrej, SULYOK, Márton, KISS, Lilla Nóra. Measuring the 'EU’clidean Distance between EU Law and the Hungarian Constitutional Court - Focusing on the Position of the EU Charter of Fundamental Rights. Czech Yearbook of Public and Private International Law, 2019, vol. 10, no. 1, p. 140.

4 MARTINICO, Guiseppe. The tangled complexity of the EU constitutional process: the frustrating knot of Europe. London: Routledge, 2014, p.93. 
inate democratic deficits in the MS, as well as discuss how legal practices laid down in fundamental treaties can further be implemented in practice. Taking into account the said above, the research will be conducted using qualitative data collection methods, by analyzing in depth the available academic publications, policy documents, reports and speeches, legislation, EU treaties, case law, preparatory documents, as well as current media reports and other sources.

\section{Challenges of EU fundamental values}

It is well-accepted that the development and creation of the EU was mainly rooted from the idea of maintaining free movement of workers, goods, services and capital. In other words, the core idea in this respect seems to be grounded on the freedoms of internal market, yet not the rule of law and democracy. However, it shall be noted that accession to the European Economic Community (EEC) of Greece, Spain and Portugal had a politically strong undertone, as membership of these countries was largely considered to result from the end of respective political regimes in those countries and by their subsequent transition of democratic society ${ }^{5}$.

Competences of the European Union have gradually enlarged, ranging from single market economy to democracy, justice and even collaboration in a shared foreign and security policy. Eventually, the EU has become a big supporter of human rights and democracy and promoter of these values that was, in its turn, well reflected on its daily policies. However, the role of EU in upholding the rule of law and democracy in the MS seems to be one of the less developed areas that could be identified as isolated from the scope of its policy domain ${ }^{6}$.

As stated by the ECJ, legal system of the EU is built on the fundamental principle that requires each MS share with other MS values set out in the Article 2 of the TEU and accept EU's foundation on the principle of shared values. Thus it can be noted that the principles set out in the Article 2 of TEU comprise very 'untouchable heart' of the EU legal order. Therefore, it can be said that these values marked the peculiarity of the integration process where it led to believe from the beginning that it was only open to those states that adhere to the rule of law, respect human rights and provide their security.

These ideas were confirmed further in various declaration of EEC institutions and were engraved in the founding treaties. For instance, these core values were comprehensively articulated and found their very expression in 1993 Copenhagen accession requirements where it was intended to shift these previ-

5 GOUDAPPEL, Flora A.N.J., HIRSCH BALLIN, Ernst M.H. (editors). Democracy and rule of law in the European Union: essays in honour of Jaap W. de Zwaan. The Hague, The Netherlands: Asser Press, 2016, p.13.

6 OREND, Brian. Human rights: concept and context. Peterborough, Ont.: Broadview Press, 2002, p.233. 
ously unwritten principles now at the core of Article 2 of the TEU to Central and Easter European candidate countries ${ }^{7}$.

It is true that dissolution of the Soviet Union and the fall of the Berlin Wall was the decisive moment in the history of the EU. It was clearly envisaged that Europe's political separation would not continue and membership to the Union of Central and Eastern European states would become a common intention. Meanwhile, it must be noted that there was huge gap between the images of Western and Eastern parts of Europe ${ }^{8}$.

As it is well established that in order to join the EU, countries must meet some criteria. As it was the case with former socialist states, they were considered by the Commission to have met that political criteria to suffice to join the EU by becoming constitutional democracies before their accession. As stated above, the European Council in Copenhagen in 22 June 1993 established those criteria that shall be met by the candidate countries prior to their accession to the EU. These include, among others, stability of state institutions, guarantee of democracy and human rights, supremacy of law, respect for the minorities rights and their protection, capacity to implement the EU acquis?.

In spite of the actual situation, the EU mainly succeeded to form positive image of some of these newly acceded states. For instance, reports concerning Romania and Bulgaria revealed that joining of these countries to the EU have brought up issues of corruption, organized crime and inability of respective judicial systems to react in this respect that could jeopardize the rule of law in these states. However, the EU tried not to highlight and focus on these issues ${ }^{10}$.

Moreover, problems affecting the rule of law could also be observed in states such as Greece and Italy together with Hungary, Romania and Bulgaria. Both in Greece and Italy corruption and lengthiness of the judicial trials were among the serious concerns that had a negative impact on the rule of law ${ }^{11}$.

In her work 'The growing role of the Union in Protection of Rule of Law' Helena Raulus highlighted several crises of rule of law in the EU, i.e., 2010

7 KELLERBAUER, Manuel, KLAMERT, Marcus, TOMKIN, Janathan. The EU Treaties and the Charter of Fundamental Rights: a commentary. Editorial: Oxford, United Kingdom: Oxford University Press, 2019, p.23.

8 GOUDAPPEL, Flora A.N.J., HIRSCH BALLIN, Ernst M.H. (editors). Democracy and rule of law in the European Union: essays in honour of Jaap W. de Zwaan. The Hague, The Netherlands: Asser Press, 2016, p.226.

9 FUREDI, Frank. Populism and the European culture wars the conflict of values between Hungary and the EU. London New York, Ny Routledge, 2018, p.16.

10 FREYBURG, Tina, et al. Democracy promotion by functional cooperation: the European Union and its neighbourhood. Basingstoke; New York: Palgrave Macmillan, 2015, p.33.

11 GOUDAPPEL, Flora A.N.J., HIRSCH BALLIN, Ernst M.H. (editors). Democracy and rule of law in the European Union: essays in honour of Jaap W. de Zwaan. The Hague, The Netherlands: Asser Press, 2016, p.185. 
restriction of Roma people's rights in France, 2012 crises of rule of law in Romania concerning the compliance issues with the decisions of constitutional courts and, of course, continuing crises of rule of in Hungary starting from $2011^{12}$.

While M.Shackleton suggests, that an entirely new political agenda has come to dominate the EU: the fallout from the 2008/9 financial crisis, the associated Euro crises, the failure to find a common response to the migration crisis, the UK leaving the EU in 2019, and the arrival of a number of governments, especially in Poland, Hungary, and Italy, deeply hostile to much of what the European Union does and stands for - all these compounded by a large dose of skepticism about the values of the EU ${ }^{13}$.

It is undeniable that in case of Hungary at present, we can see the most obvious case of threatening of the liberal democracy where all its aspects are affected, including system of checks and balances, human rights and freedoms and, of course, rule of law. The 2013 Tavares report of the European Parliament concerning the situation of fundamental rights in Hungary, its standards and practices, highlighted the challenges of principle of separation of power among independent state institutions, system of checks and balances and its proper functioning for the maintenance of rule of law in the country. These principle and instruments are considered to comprise the main pillars of the rule of law and legal order in the $\mathrm{EU}^{14}$.

At the same time, it shall be noted that while Europe is undergoing anxious period due to occurrence of the pandemic, with fears being spread among people, the Prime Minister of Hungary seems to generate privilege from declaring a state of emergency. For instance, it was pointed out by Dacian Ciolos, the President of the Renew Europe political group, that under the excuse of coronavirus the Government of Hungary has utilized these measure to limit the democratic guarantees and constitutional freedoms of ordinary people in the country ${ }^{15}$.

However, State Secretary of Hungary for international relations and communication - Zoltan Kovacs disagrees with these views. He argues that, in such a difficult time, it is not reasonable to discuss and accuse government of its way of

12 GOUDAPPEL, Flora A.N.J., HIRSCH BALLIN, Ernst M.H. (editors). Democracy and rule of law in the European Union: essays in honour of Jaap W. de Zwaan. The Hague, The Netherlands: Asser Press, 2016, p..26

13 DE FEO, Alfredo, SHACKLETON, Michael. (edit) Shaping Parliamentary Democracy: Collected Memories from the European Parliament. Cham: Springer International Publishing, 2019. Version pdf. Available at: $<>$ [Accessed: 15 May 2020], p.129

14 CARRERA, Sergio, GUILD, Elspeth, HERNANZ, Nicholas. The Triangular Relationship between Fundamental Rights, Democracy and the Rule of Law in the EU Towards an EU Copenhagen Mechanism. CEPS, 2013. Version pdf Available at: $<>$ [Accessed 12 Jun. 2020], p.18.

15 POLITICO. What should the EU do about Hungary? New bill gives Viktor Orbán sweeping new powers to fight coronavirus. . 2020. [online] 15 Apr. Available at: [Accessed 12 May 2020]. 
dealing with pandemic situation, while many EU countries also declared state of emergency and introduced special legislation. According to him, under Hungarian Fundamental Law (which will be discussed further), Government is authorized to take respective measures in state of emergency and once that state of emergency has elapsed, it will lift its decrees at issue ${ }^{16}$.

It is laid down in the Article 4(2) of the TEU that the Union shall respect the identities of the MS that reflect their inherent political and constitutional systems, as well as regional and local governments. However, it must be immediately noted that while Article 4(2) of the TEU relates to the identities of MS, there is no such equivalent provisions with regard to the identity of the Union itself. Moreover, under the EU law MS cannot legally invoke the Article 4(2) of the TEU in light of its constitutional law where it can undermine the authority of the EU law as such ${ }^{17}$.

\section{Non-compliance with EU fundamental values}

In 2009, Viktor Orban declared that the government had started to create a new Constitution, naming the existing democratic Constitution of the Republic (adopted in 1949 and amended in 1989) a series of technocratic legal norms. Within the meantime, through pursuit of its real political goals and taking advantage of the requisite two-thirds majority, the government has amended the 1989 Constitution a number of times ${ }^{18}$.

For example, a decision was taken in November 2010 to limit the constitutional court's powers to review legal norms. In the same year, the Hungarian Parliament adopted an amendment to the Hungarian Citizenship Act and, in the light of the nation's ethnic definition, implemented a new process for naturalization of Hungarians living outside Hungary. This gave ethnic Hungarians living abroad extra-territorial citizenship, claiming that the new civil policy acted as a symbolic 'cultural reunification outside borders'. There is a hidden aim behind the implicit claim that the new law serves the needs of ethnic Hungarians living abroad to get votes without real representation ${ }^{19}$.

On 18 April 2011, the Hungarian Parliament adopted a new Hungarian Constitution called 'The Fundamental Law of Hungary', which came into force on 1 January 2012 and replaced the previous Constitution of 1989. Parliament mem-

16 Ibid.

17 CHALMER, Damian, DAVIES, Gareth, MONTI, Giorgio. European Union law: cases and materials. Cambridge: Cambridge University Press, 2011, p.1020.

18 FLECK, Zoltán, GADÓ, Gábor, HALMAI, Gábor. Opinion on the Fundamental Law of Hungary. 2011. [online] Available at: https://lapa.princeton.edu/hosteddocs/amicus-tovc-english-final.pdf. [Accessed 29 May 2020], p.3.

19 FLECK, Zoltán, GADÓ, Gábor, HALMAI, Gábor. Opinion on the Fundamental Law of Hungary. 2011. [online] Available at: https://lapa.princeton.edu/hosteddocs/amicus-tovc-english-final.pdf. [Accessed 29 May 2020], p.9. 
bers who are members of the ruling party Coalition (Fidesz, KDNP) adopted the Constitution and further 7 amendments to it, without any support of opposition parties $^{20}$.

By the time the Constitution came into effect, most of the cardinal acts had not yet been enacted, and essential legislative provisions were absent in the case of acts that were enacted before the Fundamental Law was adopted. This has clearly resulted in legal confusion, the most striking example of which is that since its adoption, the current Constitution has been revised 7 times $^{21}$.

Since August 2013, after limiting the powers of autonomous state institutions such as the constitutional court, ombudsmen, and the judiciary, the government, along with state bodies, has taken action against NGOs, including tax inspections and criminal proceedings, in the manner used by authoritarian States. Such limitations explicitly contradict the European idea of democracy and the ideals of transparency and equilibrium, since NGOs and other organizations of public interest are a prime vehicle for EU citizens to both engage in policy making and keep institutions accountable 22 .

Moreover, the definition of the rule of law within the EU is regulated by an autonomous judiciary and the right to a fair trial ${ }^{23}$. Thus, Hungary has turned away from EU principles by overthrowing western democracy and the rule of $\mathrm{law}^{24}$.

As for the text itself, The Fundamental Law is introduced by a preamble that specifies the features of the legal order. Liberal democracies' constitutions are focused on acceptance of a pluralistic democratic society, separation of church and state, preferential use of a secular nation's ideology, and maintaining citizens' moral equality. Such constitutions aim to give everyone the chance to live a decent life, maintaining secular democratic ideals and freedoms. The most serious charge against the Constitutional Law preamble is the lack of certain princi-

20 BLOKKER, Paul. New democracies in crisis?: A comparative constitutional study of the Czech Republic, Hungary, Poland, Slovakia and Romania. London: Routledge, 2015, p.75.

21 BÁNKUTI, Miklós and et al. Opinion on Hungary's New Constitutional Order: Amicus Brief to the Venice Commission on the Transitional Provisions of the Fundamental Law and the Key Cardinal Laws. [online] Available at: https://lapa.princeton.edu/hosteddocs/hungary/ Amicus_Cardinal_Laws_final.pdf. [Accessed: 18 May 2020], p.4.

22 SARGENTINI, Judith. (2018). REPORT on a proposal calling on the Council to determine, pursuant to Article 7(1) of the Treaty on European Union, the existence of a clear risk of a serious breach by Hungary of the values on which the Union is founded. [online] Available at: https://www.europarl.europa.eu/doceo/document/A-8-2018-0250_EN.html [Accessed 8 Dec. 2020].

23 BÁNKUTI, Miklós and et al. Opinion on Hungary's New Constitutional Order: Amicus Brief to the Venice Commission on the Transitional Provisions of the Fundamental Law and the Key Cardinal Laws. [online] Available at: https://lapa.princeton.edu/hosteddocs/hungary/ Amicus_Cardinal_Laws_final.pdf. [Accessed: 18 May 2020].

24 LANDAU, David, LERNER, Hanna. Comparative constitution making. S.L.: Edward Elgar Publishing, 2019, p.302. 
ples. The preamble contains a list of non-neutral interrelated values, and it does not mention, for example, the principle of equality, which is clearly at odds with European Union values which appear in Article 2 TEU. ${ }^{25}$

The EU described democratic freedoms as including political pluralism, freedom of speech and religion, autonomous judicial and constitutional authorities, free and fair elections, the alternation of different political parties in government and the recognition of the opposition's role. Respect for human dignity is the primary principle set out in Article 2 TEU. Article 1 of the Charter of Fundamental Rights of the European Union (CFR) also reflects this prominence, according to which human dignity is inviolable and should be respected and protected. It is a general principle of law and has been invoked by the European Court of Justice to justify a barrier to fundamental liberties. Art. 2 TEU, as well as both CFR and TFEU (Treaty on the Functioning of the European Union), protects gender equality. Equality applies to people, and is thus another expression of non-discrimination. Non-discrimination is a principle of Union law explicitly provided for in Articles 19 and 18 of the TFEU and Chapter III of the CFR and was accepted by the Court as a basic unwritten principle ${ }^{26}$.

The Fundamental Law does not seem to endorse personal liberty, independence and equality, and this explicitly differs from the principle of dignity and equality of the EU. National and racial groups cannot engage in constitutionbuilding. That is clearly seen in the document's very first paragraph, which begins as follows: 'WE, THE MEMBERS OF THE HUNGARIAN NATION...' (all in capital letters) ${ }^{27}$.

According to Judith Sargentini, the constitutional concept of the nation in Hungary can serve as a basis for the restriction of human rights and the division of the political community. This means that members of minorities, ethnic, political, social and other groups, such as homeless people, Roma or Jewish people, are, in principle, secondary actors; they are not part of national minorities or equal to other minorities of the 'we' of the ethnic nation on whose behalf the Constitution was adopted ${ }^{28}$.

25 FLECK, Zoltán, GADÓ, Gábor, HALMAI, Gábor. Opinion on the Fundamental Law of Hungary. 2011. [online] Available at: https://apa.princeton.edu/hosteddocs/amicus-tovc-english-final.pdf. [Accessed 29 May 2020], p.3.

26 KELLERBAUER, Manuel, KLAMERT, Marcus, TOMKIN, Janathan. The EU Treaties and the Charter of Fundamental Rights: a commentary. Editorial: Oxford, United Kingdom: Oxford University Press, 2019, p.29.

27 FLECK, Zoltán, GADÓ, Gábor, HALMAI, Gábor. Opinion on the Fundamental Law of Hungary. 2011. [online] Available at: https://lapa.princeton.edu/hosteddocs/amicus-tovc-english-final.pdf. [Accessed 29 May 2020], p.7.

28 SARGENTINI, Judith. (2018). REPORT on a proposal calling on the Council to determine, pursuant to Article 7(1) of the Treaty on European Union, the existence of a clear risk of a serious breach by Hungary of the values on which the Union is founded. [online] Available at: https://www.europarl.europa.eu/doceo/document/A-8-2018-0250_EN.html [Accessed 8 Dec. 2020]. 
The Fundamental law concerns only ethnic Hungarians, who are therefore subjects of the Constitution, which leads to dilution of the theoretical foundation of minority rights on which the preceding Constitution was based, namely the fundamental principles of the multicultural model. The constitutional identity needs to remain distinct from the state's cultural identity. Because the Fundamental Law employs the idea of an ethnic community, Hungary's constitutional identity is determined by the ethnic form of national identity. An ethnic nation's primary position may jeopardize the state's democratic nature, which once bound national and state building together ${ }^{29}$.

Article L (1) preserves the family as the basis for the 'nation's survival'. The family, as understood in the Constitution, is focused on marriage between a man and a woman and the parent-child relationships. This clause may result in restrictions on the autonomy of women in respect of their freedom of reproductive functions, the rights of sexual minorities and the rights of childless couples. Further, Article II shall guarantee the right to life and the right to human dignity. The statement that 'the life of the fetus is protected from the moment of conception' and the clause that 'everyone has the right to life' are contained in one paragraph, which could later serve as a justification for the Constitutional Court to accept the right of the fetus to life and to deprive women of the right to abortion $^{30}$.

By virtue of Article VII, the state can differentiate between churches and other religious groups, and the state would collaborate only with churches in the pursuit of community objectives. The implementation of this new rule may constrain the freedom to build new churches in Hungary, consecutively leading to limited freedom of religion. Since the word 'ethnic nation' is synonymous with Christianity, such laws and practices are discriminatory in nature and restrictive for religious minorities freedom of religion ${ }^{31}$.

Article X (3) infringes the autonomy of universities as it enables the government to intervene more generally in their operation, allowing the government to apply policies regulating the management and supervision of public higher

29 BÁNKUTI, Miklós and et al. Opinion on Hungary's New Constitutional Order: Amicus Brief to the Venice Commission on the Transitional Provisions of the Fundamental Law and the Key Cardinal Laws. [online] Available at: https:/lapa.princeton.edu/hosteddocs/hungary/ Amicus_Cardinal_Laws_final.pdf. [Accessed: 18 May 2020], p.51.

30 SARGENTINI, Judith. (2018). REPORT on a proposal calling on the Council to determine, pursuant to Article 7(1) of the Treaty on European Union, the existence of a clear risk of a serious breach by Hungary of the values on which the Union is founded. [online] Available at: https://www.europarl.europa.eu/doceo/document/A-8-2018-0250_EN.htm [Accessed 8 Dec. 2020].

31 FLECK, Zoltán, GADÓ, Gábor, HALMAI, Gábor. Opinion on the Fundamental Law of Hungary. 2011. [online] Available at: https://lapa.princeton.edu/hosteddocs/amicus-tovc-english-final.pdf. [Accessed 29 May 2020], p.25. 
education institutions $\mathrm{s}^{32}$. For instance, after a legal war with the government, the Central European University was forced out of the country and moved its accredited programs to Vienna ${ }^{33}$.

\section{EU mechanisms to safeguard fundamental values}

Several MS, and not just Hungary, retrospectively demonstrated contempt for the principles enshrined in Art.2 TEU. As the 'Guardian of Treaties', the Commission used a variety of methods to resolve the issue.

The EU has developed policy mechanisms to safeguard rule of law, human rights and democracy. Policy instruments help the EU evaluate and track compliance in its MS with the rule of law and human rights. Political instruments are essential as they warn the EU about the problems in the MS in the sphere of democracy, human rights and the rule of law, as well as establish a cooperation mechanism between the Union institutions and the MS. Policy instruments address critical topics and make recommendations that are non-binding. However, as they do not contribute to penalties, such mechanisms will only be useful when MS wishes to cooperate and change policies and legislation ${ }^{34}$.

At first, the so-called 'soft power' of political persuasion seemed to be very successful. However, this strategy wasn't able to produce particularly successful results in reality. Because approaches such as negotiation and discussion, which bear no mandatory responsibility, are only successful when the other party is willing to collaborate. The opposing parties, namely MS, which practiced noncompliance with Art.2 of the TEU, were thus ignorant to the steps suggested by soft power mechanism in most cases. However, the soft power process, as interpreted by some scholars, was a precursor to the Commission system called 'A new EU framework to strengthen the rule of law'35.

The new Mechanism is an 'early warning tool' method with a three-stage process, ready to resolve any issues relevant to the rule of law in a MS through a formal dialog before a serious threat may occur. The first stage includes the

32 SARGENTINI, Judith. (2018). REPORT on a proposal calling on the Council to determine, pursuant to Article 7(1) of the Treaty on European Union, the existence of a clear risk of a serious breach by Hungary of the values on which the Union is founded. [online] Available at: https://www.europarl.europa.eu/doceo/document/A-8-2018-0250_EN.html [Accessed 8 Dec. 2020].

33 BENKOVÁ, Lívia. Hungary-Orbán's project towards 'illiberal democracy.' 2019. [online] pp.1-4. Available at: https://www.aies.at/download/2019/AIES-Fokus-2019-02.pdf [Accessed 11 Oct. 2020].

34 GOUDAPPEL, Flora A.N.J., HIRSCH BALLIN, Ernst M.H. (editors). Democracy and rule of law in the European Union: essays in honour of Jaap W. de Zwaan. The Hague, The Netherlands: Asser Press, 2016, p.32.

35 BUNGENBERG, Marc. and HAZARIKA, Angshuman. Rule of Law in the EU Legal Order. ZEuS Zeitschrift für Europarechtliche Studien, Volume 22(3), 2019, pp.383-406. [online] Available at: https://doi.org/10.5771/1435-439X-2019-3. [Accessed 27 Jun. 2020], p.392. 
compilation of information from all available sources. If there is a challenge to the rule of law, the Commission must submit its opinion to obtain a response and initiate a dialog 36 .

If the first stage is not satisfactory, then the Commission would submit a logical proposal to a MS outlining how to address the undesirable situation with a reasonable deadline, which the Commission would make public. The Commission tracks the measures taken by MS towards the criteria set out in the recommendation in the last point. And again, if the procedure is unsuccessful, the Commission has no choice but to apply Art. 7 TEU as a last resort, which is also important to safeguard other values prescribed in Art.2 TEU, not just the rule of $\mathrm{law}^{37}$.

Thanks to European and international monitoring mechanisms, the EU is well informed about the situation concerning human rights, democracy and the rule of law in Hungary. Yet without the assistance of legislative instruments, such political instruments themselves are not powerful enough in cases where there is no desire to participate in constructive dialog with European institutions on behalf of a MS. EU institutions do require procedural frameworks in such situations, such as the non-compliance to legal proceedings ${ }^{38}$.

If issues relating to the values mentioned in Art.2 TEU emerge in a MS, the EU Commission may have recourse to two main legal procedures: it may bring a case for failure to comply with acquis - infringement procedure under Article 258 of the TFEU and/or it may bring a case under Article 7 of the TEU, which safeguards the fundamental principles of the EU and MS from systemic shortcomings. However, other Treaty mechanisms could either be applicable ${ }^{39}$.

Procedure under Article 258 TFEU is referred to as infringement proceedings and is valid if MS refuses to meet its obligations under the Treaties and is also carried out in three stages. Beginning with a formal notice to the MS and following with a reasonable opinion, the Commission may take the matter as a last resort before the CJEU. So, the court must examine those charges in the case of an accusation of non-performance, and if the country is found guilty, it must instantly correct the situation.

The Commission used the infringement proceedings against Hungary when a compulsory retirement age (62) was introduced for judges by the Government.

36 COMMUNICATION FROM THE COMMISSION TO THE EUROPEAN PARLIAMENT AND THE COUNCIL (2014). A new EU Framework to strengthen the Rule of Law.

37 Ibid.

38 GOUDAPPEL, Flora A.N.J., HIRSCH BALLIN, Ernst M.H. (editors). Democracy and rule of law in the European Union: essays in honour of Jaap W. de Zwaan. The Hague, The Netherlands: Asser Press, 2016, p.32.

39 KELLERBAUER, Manuel, KLAMERT, Marcus, TOMKIN, Janathan. The EU Treaties and the Charter of Fundamental Rights: a commentary. Editorial: Oxford, United Kingdom: Oxford University Press, 2019, p.26. 
Court of Justice of the European Union (CJEU) declared that MS failed to fulfill obligations under Art.2 and 6(1) of Council Directive 2000/78/EC establishing a general framework for equal treatment in employment and occupation ${ }^{40}$.

This procedure is used to check whether individual regulations of MS and practices of public authorities comply with EU law, and it is not a tool by which systematic violations of the rule of law can be considered. Furthermore, no action will be possible in areas not regulated by EU law, or in a situation where the national violation of EU values is purely political and diffuse ${ }^{41}$. Thus, the possible initiation of infringement proceedings in compliance with Article 258 TFEU can cover only those acts of MS which fall within the scope of EU law ${ }^{42}$.

The procedure laid down in Article 7 is also introduced by the Commission on the basis of the subsidiarity principle, i.e. if the institutions of MS are unable to adequately cope with the democratic deficit. This shows the importance of Article 7 that, in addition to the judicial process, it is the only supervisory agency in the hands of the European institutions to monitor and evaluate MS compliance with the fundamental principles of the Union set out in Article 2 of the TEU. The procedures set out in Art.7 for safeguarding values under Art.2 TEU consist of three different types: preventive measures for a clear risk of serious violation of the values set out in Art 2 TEU, a procedure to state that there is a serious and persistent breach of those values, and sanctions for serious and systematic breach of those values. The application of Article 7 may result in the suspension of rights arising from the application of the Treaties to a $\mathrm{MS}^{43}$.

The rigidity of the sanctions provided for in Article 7 TEU makes it possible to apply them only in an impasse. The procedure referred to in Art.7 has only been applied twice so far and only as a preventive measure in the proceedings against Poland in 2017 and against Hungary in 2018. Against Hungary, the procedure has been applied in connection with all the issues discussed above, namely: independence of the judiciary, functioning of the constitutional and electoral system, corruption and conflicts of interests, academic freedom and treatment, rights of minorities ${ }^{44}$.

40 CJEU, Case C-286/12, Commission \& Hungary, ECLI:EU:C:2012:687 [2012] eur-lex.europa.eu.

41 KOCHENOV, Dimitry, PECH, Laurent. Monitoring and Enforcement of the Rule of Law in the EU: Rhetoric and Reality. European Constitutional Law Review, vol. 11, no. 3, p.520.

42 HAMULÁK, Ondrej, SULYOK, Márton, KISS, Lilla Nóra. Measuring the 'EU'clidean Distance between EU Law and the Hungarian Constitutional Court - Focusing on the Position of the EU Charter of Fundamental Rights. Czech Yearbook of Public and Private International Law, 2019, no. 1, p. 140.

43 KELLERBAUER, Manuel, KLAMERT, Marcus, TOMKIN, Janathan. The EU Treaties and the Charter of Fundamental Rights: a commentary. Editorial: Oxford, United Kingdom: Oxford University Press, 2019, p. 91.

44 BUNGENBERG, Marc. and HAZARIKA, Angshuman. Rule of Law in the EU Legal Order. ZEuS Zeitschrift für Europarechtliche Studien, vol. 22, no.3, pp.383-406. [online] Available at: https://doi.org/10.5771/1435-439X-2019-3. [Accessed 27 Jun. 2020], p.396. 
Sanctions mechanism for the severe and persistent violation of the values in Art.2 TEU by MS is a quite complicated process, as the procedural threshold is very high. Nevertheless, it may suspend other MS rights when implemented, including voting rights of MS. This technique has not yet been used, but some scholars state that it could be used against Hungary for sure, where it does have a theoretical basis for its application ${ }^{45}$.

The EC has other tools as well to provide an early warning and prevent threats on EU values. They are: The European Semester, the EU Justice scoreboard, EU funds to support public administration and judiciary and fight corruption and others $^{46}$.

Today, the question is what Europe can do about the MS democratic deficit and how it can stand up for the principles set out in Article 2 of the TEU and its sustainable democratic development. The proposal of developing a new mechanism was introduced in connection with this problem, so that the infringement of the principles enshrined in Article 2 could be removed. The possibility of using 'nuclear weapon' pursuant to Article 7(2) is still under consideration. Since other methods have so far been ineffective, results have yet to be predicted, but we can't say they will be either positive or negative.

\section{Conclusion}

The analysis explored the relationship between the national identity of the state and the security of fundamental values of the EU using the example of the Hungarian Fundamental Law. As it was found, the legal act describes the nation's ethno-cultural framework as a Christian culture and institutionalizes an obsolete approach with theological overtones to nationalistic history. The Fundamental Law serves for state's interests, not moral principles, which in itself undermines liberal democracy leading to a liberal catastrophe. Hungary, although the EU member, is at odds with the principles chanted in Article 2 of the TEU. Criticism on the part of the EU institutions has not been followed by desired conversion and the situation worsened even more at the time of the COVID-19 crisis.

The study of the Hungarian Constitution thus indicates that the Copenhagen criteria should be streamlined and closely monitored. It should be clear that countries show their true commitment to the democratic values enshrined in Article 2 TEU when they join the EU. They should be able to remain faithful to those values and stand up for their sustainability, because the EU is founded on these very principles and values.

45 KELLERBAUER, Manuel, KLAMERT, Marcus, TOMKIN, Janathan. The EU Treaties and the Charter of Fundamental Rights: a commentary. Editorial: Oxford, United Kingdom: Oxford University Press, 2019, p.96.

46 BUNGENBERG, Marc. and HAZARIKA, Angshuman. Rule of Law in the EU Legal Order. ZEuS Zeitschrift für Europarechtliche Studien, vol. 22, no. 3, pp.383-406. [online] Available at: https://doi.org/10.5771/1435-439X-2019-3. [Accessed 27 Jun. 2020], p.397. 
The case of Hungary shows that anti-democratic regimes can also restrict judicial independence, while only an autonomous judiciary can effectively safeguard the EU values. It is impossible to enforce Article 2 of the TEU without the approval of the national courts, when there are systemic breaches of human rights, rule of law and democracy deficit.

We came to the conclusion that the mechanisms used by the EU have not yet brought the desired results. If it comes to the fundamental values of the EU and failure of a MS to comply, the EU should be able to monitor the institutional and founding principles of the MS in order to avoid non-compliance, and this should not mean the EU is interfering with the MS's sovereign rights. This research suggests increasing the rate of political participation of people, role of opposition parties and possibility of decentralization of power so that the violation of the values cherished in Article 2 could be eliminated.

\section{List of references}

DE FEO, Alfredo, SHACKLETON, Michael (edit). Shaping Parliamentary Democracy: Collected Memories from the European Parliament. Cham: Springer International Publishing, 2019. Version pdf. Available at: <https://doi.org/10.1007/978-3-03027213-5> [Accessed: 15 May 2020].

BÁNKUTI, Miklós and et al. Opinion on Hungary's New Constitutional Order: Amicus Brief to the Venice Commission on the Transitional Provisions of the Fundamental Law and the Key Cardinal Laws. [online] Available at: <https://lapa.princeton.edu/hosteddocs/hungary/Amicus_Cardinal_Laws_final.pdf >. [Accessed: 18 May 2020].

BENKOVÁ, Lívia. Hungary-Orbán's project towards 'illiberal democracy'. 2019. [online] pp.1-4. Available at: https://www.aies.at/download/2019/AIES-Fokus-2019-02.pdf [Accessed 11 Oct. 2020].

BLOKKER, Paul. New democracies in crisis?: A comparative constitutional study of the Czech Republic, Hungary, Poland, Slovakia and Romania. London: Routledge, 2015.

BOUTROS-GHALI, Boutros. Interdependence of democracy and development. France, SHS-2003/WS/24, UNESCO, 2003.

BUNGENBERG, Marc. and HAZARIKA, Angshuman. Rule of Law in the EU Legal Order. ZEuS Zeitschrift für Europarechtliche Studien, Volume 22(3), 2019, pp.383-406. [online] Available at: <https://doi.org/10.5771/1435-439X-2019-3>. [Accessed 27 Jun. 2020].

CARRERA, Sergio, GUILD, Elspeth, HERNANZ, Nicholas. The Triangular Relationship between Fundamental Rights, Democracy and the Rule of Law in the EU Towards an EU Copenhagen Mechanism. CEPS, 2013. Version pdf Available at: $<$ http://www.ceps. eu> [Accessed 12 Jun. 2020].

CHALMER, Damian, DAVIES, Gareth, MONTI, Giorgio. European Union law: cases and materials. Cambridge: Cambridge University Press, 2011.

CJEU, Case C-286/12, Commission \& Hungary, ECLI:EU:C:2012:687 [2012] eur-lex. europa.eu (JUDGMENT OF THE COURT (First Chamber)) Failure of a Member State to fulfil obligations - Social policy - Equal treatment in employment and occupation - Directive 2000/78/EC - Articles 2 and 6(1) - National scheme requiring compulsory retirement of judges, prosecutors and notaries on reaching the age of 
62 - Legitimate objectives justifying a difference in treatment vis-à-vis workers under the age of 62 - Proportionality of the duration of the transitional period.

COMMUNICATION FROM THE COMMISSION TO THE EUROPEAN PARLIAMENT AND THE COUNCIL (2014). A new EU Framework to strengthen the Rule of Law.

FLECK, Zoltán, GADÓ, Gábor, HALMAI, Gábor. Opinion on the Fundamental Law of Hungary. 2011. [online] Available at: https://lapa.princeton.edu/hosteddocs/amicusto-vc-english-final.pdf. [Accessed 29 May 2020].

FREYBURG, Tina, et al. Democracy promotion by functional cooperation: the European Union and its neighbourhood. Basingstoke; New York: Palgrave Macmillan, 2015.

FUREDI, Frank. Populism and the European culture wars the conflict of values between Hungary and the EU. London New York, Ny Routledge, 2018.

GOUDAPPEL, Flora A.N.J., HIRSCH BALLIN, Ernst M.H. (editors). Democracy and rule of law in the European Union: essays in honour of Jaap W. de Zwaan. The Hague, The Netherlands: Asser Press, 2016.

HAMULÁK, Ondrej, SULYOK, Márton, KISS, Lilla Nóra. Measuring the 'EU'clidean Distance between EU Law and the Hungarian Constitutional Court - Focusing on the Position of the EU Charter of Fundamental Rights. Czech Yearbook of Public and Private International Law, 2019, vol. 10, no. 1, pp. 130-150.

KELLERBAUER, Manuel, KLAMERT, Marcus, TOMKIN, Janathan. The EU Treaties and the Charter of Fundamental Rights: a commentary. Editorial: Oxford, United Kingdom: Oxford University Press, 2019.

KOCHENOV, Dimitry, PECH, Laurent. Monitoring and Enforcement of the Rule of Law in the EU: Rhetoric and Reality. European Constitutional Law Review, 2015, vol. 11, no. 3, pp. 512-540.

LANDAU, David, LERNER, Hanna. Comparative constitution making. S.L.: Edward Elgar Publishing, 2019.

MARTINICO, Guiseppe. The tangled complexity of the EU constitutional process: the frustrating knot of Europe. London: Routledge, 2014.

OREND, Brian. Human rights: concept and context. Peterborough, Ont.: Broadview Press, 2002.

POLITICO. What should the EU do about Hungary? New bill gives Viktor Orbán sweeping new powers to fight coronavirus. www.politico.eu. 2020. [online] 15 Apr. Available at: https://www.politico.eu/article/what-should-the-eu-do-about-hungary-coronavirusviktor-orban/amp/ [Accessed 12 May 2020].

SARGENTINI, Judith. (2018). REPORT on a proposal calling on the Council to determine, pursuant to Article 7(1) of the Treaty on European Union, the existence of a clear risk of a serious breach by Hungary of the values on which the Union is founded. [online] Available at: https://www.europarl.europa.eu/doceo/document/A-8-2018-0250_ EN.html [Accessed 8 Dec. 2020]. 